\title{
АНТРОПОЛОГИЧЕСКАЯ МОЗАИКА
}

УДК $39+355 / 359$

DOI: $10.33876 / 2311-0546 / 2020-50-2 / 193-205$

(C) Н.А. Белова

\section{«РЫЦАРИ БЕЗ СТРАХА»: ВОСПОМИНАНИЯ УЧИТЕЛЕЙ - УЧАСТНИКОВ ВЕЛИКОЙ ОТЕЧЕСТВЕННОЙ ВОЙНЫ*}

\begin{abstract}
В статье на основании эго-документов рассказываются фронтовые истории учителей, принимавших участие в Великой Отечественной войне. Эти истории были записаны ещуе к 20-летию победы, но иензура советского времени не допустила сборник к печати. Мемуары, сохранившиеся в Государственном архиве Костромской области (ГАКО), свидетельствуют об ужасных событиях того времени, когда выражение «мирное небо» становится символичныли. Важность этих эго-документов заключается в том, что они являются прямым свидетельством тех событий, которые произошли 75 лет назад. В каждой российской семье есть герои-участники этого исторического события, кто-то из них сражался, а кто-то работал в тылу и нама задача рассказывать об этих подвигах, чтобы они не предавались забвению. Именно поэтому мы подготовили статью, в которой советские учителя вспоминают о жизни, подвигах, быте на фронтах Великой Отечественной войны. Мы попытались рассказать об основных аспектах того трудного периода, о том как людям приходилось выживать и выходить из душевного кризиса после пережитых потрясений.
\end{abstract}

Ключевые слова: эго-документы, Великая Отечественная война, жизнь, фронт, подвиги, учителя

О Великой Отечественной войне 1941-1945 гг. написано немало работ, опубликованы мемуары, воспоминания и другие эго-документы как первых государственных лиц, так и простых людей, которые описывают события того времени. Но помнить и публиковать новые свидетельства о событиях того времени - наш первостепенный долг. Чтобы мы умели ценить и радоваться каждому мирному дню, чтобы не забывали, что счастье рядом и оно в мелочах, важно понимать цену военных побед! Наша жизнь стала стабильной, хорошей и спокойной. Большинство из нас сейчас могут съездить в другую страну, позволить себе отдых на море или в самом крайнем случае поехать отдыхать на дачу. А ведь всего 75 лет назад наши соотечественники

Белова Наталья Андреевна - к.и.н., научный сотрудник ЦЭПИ Института этнологии и антропологии РАН (Москва, Ленинский пр. 32-А). Эл. почта: belovanatalia1986@gmail.ru. Belova, Natalya A. - Institute of Ethnology and Anthropology, RAS (Moscow, Leninsky Prospect 32-A). E-mail: belovanatalia1986@gmail.ru.

* Публикуется в соответствии с планом научно-исследовательских работ Института этнологии и антропологии РАН 
часто не имели газовой плиты, горячей воды и водопровода в доме. Электричество в некоторых районах СССР появилось только после войны и то иногда благодаря учителям и местным активистам. Например, в 1947 году мой дед бегал в школу посмотреть как горит лампочка, потому что для деревенской ребятни это было чудом, а в дом он провел электричество своим родителям только в 1960-е годы, когда закончил техникум и стал электриком. Что говорить о других технических достижениях - стиральной машине, холодильнике и др., которыми мы сейчас пользуемся в быту, и не замечаем насколько комфортной и легкой стала наша жизнь.

Великая Отечественная война повлияла на судьбы всех россиян и осталась в нашей памяти навсегда. В каждой российской семье есть герои-участники войны, ктото из них сражался, а кто-то работал в тылу. Но сейчас все меньше очевидцев той трагедии, тех, кто совершил великий подвиг и может нам рассказать о тяжелых днях военного времени. Именно поэтому сбор материалов, их публикация, переосмысление будут всегда актуальны для изучения.

История Великой Отечественной войны стала анализироваться, описываться и собираться почти сразу после ее завершения. Наверное, это самый изученный период XX века, но вместе с тем он и самый трагичный, требующий постоянного переосмысления и рассмотрения. Все новые и новые источники находятся в архивах или в библиотеках, которые проливают свет на те темные страницы истории XX века.

В этой статье мы хотели бы рассказать об учителях и о событиях 1941-1945 гг. по их воспоминаниям, сохранившимся в Государственном архиве Костромской области (ГАКО). Эти эго-документы не были опубликованы, а были собраны в виде интервью и записаны местными активистками-учительницами к 25-летию Победы в Великой Отечественной войне. Так получилось, что сборник в то время не издали. Вероятно, он не прошел цензуру, потому что во многих случаях рассказы отражали действительность без прикрас. Например, воспоминания учителя-узника Бухенвальда, записи о блокаде Ленинграда, о заградотряде, об оснащении войск в первые дни войны и многом другом, что было недопустимо к огласке с позиции советского руководства 1970-х годов. Некоторые пережившие войну учителя оправдывались что попали в плен, другие, почему не воевали, а работали на общественных должностях, почему их деятельность не была геройской и «бить фашистов» им не довелось, а пришлось только участвовать в хозяйственной жизни армии. Но вместе с тем вклад большинства советских людей недооценивать нельзя и поэтому в этой статье мы хотели бы рассказать какими запомнились непростые военные годы учителям, представителям - одной из самых многочисленных социальных групп в СССР. Что пережили те, кто в мирной жизни занимается совсем другим делом, не имеющим ничего общего с оружием, для кого главное средство в жизни - это книга, перо и бумага? Как люди интеллигентных профессий вспоминают те непростые годы жизни на фронте? Что для них было самым сложным, и что помогло не впасть в уныние в сложные минуты, граничащие с отчаянием?

\section{Фронтовые были}

В этой части статьи мы собрали наиболее интересные героические истории учителей, которые показывают их смелость, решительность и храбрость, переживания военного времени были наполнены зачастую страхом и ужасом от возможной смерти или плена. Но в то же время хочется отметить скромность этих людей и некоторое прини- 
жение своих собственных заслуг. Делясь воспоминаниями, с большим желанием они рассказывали о подвигах товарищей, чем о своих. Многие просто не хотели описывать свои истории, потому что им это давалось нелегко - вспоминать гибель товарищей, переживать заново панику и растерянность... Снова вспоминать унижения и свое бессилие перед хорошо вооруженной немецкой армией, да и другие ужасы войны.

Смирнов А.П.: В декабре 1941 г. полк получил приказ выехать и войти в состав Северо-Западного фронта. Машины были в вагонах в разобранном виде. Мы выгрузились и стали перевозить самолеты и имущество на аэродром, расположенный в трех километрах от станиии. Полку было приказано в десятидневный срок собрать машины. В тридиатиградусный мороз, при сильном ветре весь состав полка приступил к сборке машин. Механики и техники, помогали летчики и итурмань, механики по вооружению, приборам. Приказ был выполнен в срок. Многие механики и техники, работая гольми руками, обморозили руки, но не уходили в санчасти и приказ выполнили.

Лежнин Александр Архипович: 30 декабря 1941 2. наша часть была выброшена десантом в город Феодосию в Крыму. Очистив город от немиев, дивизия заняла оборону в 20 км севернее Феодосии. За 10 дней была высажена с моря одна дивизия пехоты, но танков и артиллерии было мало. Воспользовались этим немиь и 17 января перешли в наступление, окружили Феодосию. Выход из окружения был неорганизованный. Рота моя давала связь, в разных направлениях мелкими группами выходила с теми частями, к которым были приданы. Из окружения вышла малая доля. Потери людские были с нашей стороны большие. Вышедшие из окружения, 18 января вновь заняли оборону на перешейке Керченского полуострова от Черного моря до Азовского на протяжении 18 км. Зима была сурова и в Крыму. В 20-х числах января Керченский пролив покрылся льдом и к нам стало подступать пополнение людьми, техникой и продовольствием. Наш фронт держался до 3 мая 1942 г. Много раз наши части переходили в наступление, но по разным причинам движение было слабое. Немць не только упорно сопротивлялись, но и переходили в контрнаступление. С 1 мая наша дивизия отошла на 10 км в тыл на отдых, помыться в полевой бане (не мылись с 20 декабря) и сменить белье. 3 мая немцы начали крупное наступление с авиаџией, танками и артиллерией. Наши передовые части были сбиты, а с восходом солнца начался бой. Авиация противника в течение двух часов бомбила наши окопь, смешала все укрепления с землей. Пыль и дым поднялись на сотни метров, мы были как в густом тумане. Полк, которому мы вели связь, начал отступать, оставляя убитых и раненых. А в это время две плотные шеренги автоматчиков-фашистов пошли на нас в атаку. В передней линии оказалось мое отделение связистов. Мы открыли винтовочный огонь. Отстреливаясь, нам пришлось отступать до обороны, которую занял полк. Я был ранен в грудь. Связь со штабом дивизии прекратилась. Я выбыл из строя. Два дня пробирался до Керчи. Здесь ила эвакуачия на материк. Вечером 10 мая раненые были погружены на две баржи, которые с наступлением полной темноты, небольшой катер потянул через пролив шириной 12 м в Тамань. Когда мы были на середине пролива, произошел налет немецкой авиации. Самолеты выбросили множество парашютных ракет. Стало светло, как в роковом рассвете. Началась бомбежка. Баржа, шедшая впереди нас, была разбита. Тогда катер повернул обратно, подобрал кого мог из тонущих и раненых и вернулся в Керчь, оставив нашу баржу на середине пролива. 
Я находился в состоянии полузабытья и был равнодушен ко всему происходящему. Но ходячие больные несколько раз поднимали страшный шум, почему же нас бросили.

Рассвело. Взошло солнце. Наша баржа тихо покачивалась на мертвой морской зыби. Были видны и Тамань, и Керчь. Только часов в 12 дня катер пришел из Керчи с новой баржей раненых, прицепил нашу баржу и часа через два мы были в Тамани.

Сумкин И.И.: Помню в начале октября 1943 г. наш отряд, продвигаясь на запад, остановился на краткосрочный отдых в небольшом лесу в трех-четырех километрах от села Крутая Житомирской области. Вечером к нам в лес вся в слезах прибегает крестьянская девочка и сообщзает, что в село пришли немцьь-каратели, часть жителей села расстреляли, а женщин, стариков и детей согнали в школу, заперли их там и намерены сжечь школу. Медлить было нельзя. Командир отряда Орловский приказал командиру Грабову немедленно со взводом выступить и освободить жителей села, спасти их от неминуемой гибели. Задача была выполнена. Используя момент внезапности, в коротком, но жарком бою многие фашисты были убиты, конечно, были и потери со стороны партизан. Трудно было описать радость смертников - женщин, детей и стариков, освобожденных партизанами из заключенной школьл.

Лежнин В.И.: В апреле месяще в 1943 г., при налете на наш аэродром немџь интенсивно бомбили, и одна из бомб упала рядом с щелью, в которой находился я и ещзе два механика. Нас засыпало землей. После налета вражеской авиации нас откопали. Из троих живым оказался только я, но в бессознательном состоянии. Меня контузило, и я был отправлен в госпиталь в г. Вышний-Волочек, а оттуда тяжело раненный в глубокий тыл - Казань. Очнулся я в Казани на 14 сутки. Два месяча не говорил и не сльшал ничего, да и видел очень плохо. После двух месяцев вернулся слух, а потом стал понемногу разговаривать. Постепенно восстановилось и зрение. Несмотря на это был отправлен снова на фронт. После выздоровления был направлен в Кострому на учение, получил звание лейтенанта на должность саперного взвода. За время боевых действий поставили около 2-х тысяч противотанковых и противопехотных мин и сняли около 3-х тысяч мин противника. Наводили переправы и стоили мосты для пропуска боевой техники своего полка, строили наблюдательные и командирные пункты, строили ДЗОТы, помогали пехоте в устройстве окопов и траншей. Приходилось несколько раз сходить в тыл противника на подрыв мостов. Из шести заданий не выполнено было только два.

Из письма Теплякова Ф.П.: «Mы засиделись на одном месте. Не оправдываем заботу тыла о нас. Ещее не истребили всех фрищев. Нас радуют успехи товарищей по оружию. Взят Курск, и как только возьмем Брянск, Орел, Смоленск, знайте в этом есть частичка и нашего труда. Получаем новые знаки на погонах - будем настоящими русскими офицерами, верными солдатами Родины, какими были твои и мой отеи». Воспоминания о нем написала его жена, которая осталась в тылу с тремя детьми и в переписке рассказывала о трудностях жизни тыла и работы. Он часто писал ей и поддерживал ее письмами, полными бодрости и уверенности в победе. Он погиб в июле 1943 г. под Орлом.

Воспоминания о партизанской разведке Грабова А.В.: Было это зимой 19442. недалеко от райцентра Городница, что стоит на берегу р. Случ. Из расположения отряда вышли днем, прошли километров 10-15 и решили зайти в деревню отдох- 
нуть и перекусить. Точнее говоря, деревни-то уже не было. Сожгли ее немиь, и крестьяне ютились в землянках, наскоро построенных возле самого леса.

Зашли в одну из землянок, попросили хозяйку сварить картошки. Бойща Скрипку послали на разведку обстановки в деревне, осмотреть другие землянки и, если удастся, достать у жителей сколько-нибудь хлеба к обеду. В землянке остались начальник штаба отряда Смирнов, боеи Мельниченко, медсестра Лена Толокевич и сам А.В. Грабов.

Вдруг, неожиданно в землянку входит немец. Грабов не растерялся. Короткой очередью из автомата сразил немціа и побежал к выходу. Мгновенным выстрелом уложил и второго немиа у входа в землянку. Разведчик-боеи Скрипкане, имея возможность подойти к своим, побежал в отряд и доложил, что все партизаны нарвались на немцев и все погибли во главе с Грабовым.

В перестрелке фашисты убили начальника штаба отряда Смирнова, смертельно ранили партизана Мельниченко. В землянке остались Грабов и медсестра. Положение создалось критическое.

Зная, что в этом районе-немиы поспешно отступают под натиском советских войск, Грабов предложил медсестре выскочить из землянки, назваться хозяйкой дома, сказать немцуам, что вооруженных партизан в землянке осталось ещуе много и, если они поспешно отступают, указать им путь к «своим».

Сам же Александр Васильевич остался в землянке один и продолжал вести бой через небольшие окна и дверь. Немиы неоднократно пытались поджечь землянку, но мокрая соломенная крыша не загоралась. Тогда подожги они копну сена, стоящую рядом с входной дверью. Дым начал просачиваться и в землянку, дышать было нечем.

На дворе уже стало темнеть, тлеющее сено копны создало настоящую дымовую завесу. Под прикрытием дыма и наступающей темноты Грабову удалось незаметно выйти из землянки, вынести раненого Мельниченко и скрыться в лесу. Как потом выяснилось, в этом неравном бою было убито партизанами 14 немцев, а Лена Толокевич привела 140 отступающих фашистов в Городницу, где уже находились советские войска (ГАКО. Ф. Р-551. Оп. 1. Д. 23).

Историй и рассказов очень много, это небольшая часть, которую здесь мы смогли рассказать. Очень бы хотелось упомянуть об каждом подвиге, но формат этой статьи к сожалению не позволяют больше. Вместе с тем, без сомнения каждый из участников войны внес свой вклад в победу над фашизмом, который олицетворяла Германия в те годы.

\section{Узники войны: «Как мы жили в лагерях? Да можно ли ту жизнь назвать святым словом ЖИЗНЬ?»}

Одна из самых страшных страниц войны - это истории людей побывавших в плену, именно они оказывались на пороге самых сложных душевных переживаний и испытаний. Ведь эти испытания превращались в игру «кто сильнее, тот и жив»: и проявив слабость, трусость, а порой просто поступив инстинктивно, человек неосторожным поступком мог унести сотни жизней. Думаю, что ни для кого не секрет, что фашисты были очень жестоки в отношении плененных русских, украинцев, поляков, а не только евреев. По рассказам, кадрам из фильмов, фотографиям мы видим 
садизм и ужас того времени, который психически нормальный человек не способен совершить в отношении другого человека. Вместе с тем факт остается фактом, что все события не выдумка и множество воспоминаний подтверждают это. В этом параграфе, самом противоречивом с точки зрения этики, мы бы хотели рассказать о тех варварствах и зверствах, которым пришлось пережить людям, о тех страданиях и шоке, который испытывали люди от изуверств фашистов.

Климов Дмитрий Георгиевич: Я был контужен. Долго ли лежал полузасыпанный землей, не знаю. Очнулся от тишины. Говорю, а голоса своего не сльшу. Тишина. Глухота... кругом трупы в разных позах... Вижу цеепочкой движутся немщь. Не совсем ясно, но созревает мысль - уничтожить документы. Ия зарыл их в земле под свочм конем. Нашупьваю револьвер, хочу застрелиться, чтобы не попасть в руки извергов. А выстрела нет. Пистолет забит землей. Что делать?.. Я уже обнаружен. Крики... толчки... побои... комендатура... Вместе с другими меня кидают на пол лицом вниз, руки над головой, пальцы связаны. Рядом со мной лежала женщина и ребенок. Меленькими ручонками он пытался достать до груди. Палачи смеялись. Мы видели ужас, садизм, и ничем помочь не могли. Ребенок и мать были замучены на наших глазах... А сколько других тяжельх картин видели пережили мьь!

Пока мы были в лагерях на своей территории, нас не покидала мысль: «Надо действовать! Нужен побег, пока мы на своей родине, а для этого нужна хорошая организация и руководство». Но план освобождения сорвался: предатели, к сожалению, умеют приспосабливаться везде и всюду. И нас перебросили в Германию.

Бухенвальд... Этот лагерь занимал 350 га. На воротах была надпись: «Каждому свое!». Бухенвальд... Прошло уже много времени (25 лет), но при воспоминании о нем даже теперь становиться жутко. Огромные бараки и среди них крематории, печи которого работали круглосуточно. Штабели трупов занимали свободные площзади между бараками. Было страшно и жутко... Среди убитых мы видели нашу молодежь... Чувство возмущчения не покидало нас. Ведь совсем неподалеку находились места, где жили и творили Гёте и Шиллер, где писали свою бессмертную музыку Бетховен, Лист и Вагнер.

Страх преследовал нас, не только потому что смерть смотрела на нас, а потому что сознание сверлила мысль: «Как могли циивилизованнье люди дойти до такого садизма? Могут ли они носить название ЧЕЛОВЕК?

Какмы жили в лагерях? Да можно ли ту жизнь назвать святым словом ЖИЗНЬ?

Мы пережили жуткую физическую боль от наказаний. Как часто нарушалась наша психика. Помню, как в течение долгого времени не мог вспомнить свое имя и фамилию. Были периоды полного безразличия. Но чащуе хотелось быть человеком: читать, писать, сидеть за столом, видеть себя чистым и в костюме, слушать музыку, а не лакать грязную жижу из корыта, стоя на коленях. Помню каратели лишили нас хлеба (так назывался серый комочек, испеченный неизвестно из чего), воды, картошки. Мы все были дистрофиками, при выполнении тяжельх физических работ. Казалось смерть стоит у ног. А мы перебивались, собирая друг у друга имеющиеся крохи и поддерживали слабых, учили языки, т.к. лагерь был интернациональным. Так зарождалась дружба - дружба народов.

Май 1945 г., нас привезли «домой» в г. Козельск для проверки воинских и гражданских прав. В октябре 1945 г. я демобилизовался и вернулся в Кострому. Надо было поправиться, окрепнуть, освободиться от мучительных раздумий. Наступила пора 
вернуться к нормальной человеческой жизни. В Костромском горвоенкомате встретили по-товарищески, возвратили документы, воодущевили и направили на работу военруком. Сейчас преподаю историю и считаю себя счастливым человеком, потому что живу в Советском союзе.

Батищева Ольга Эммануиловна: В Польше я видала 17 летнего юношу-поляка, освобожденного из лагеря Смерти Освенцима в числе 500 человек, оставшихся в живых. У него были перебиты позвонки, отчего весь корпус его был согнут, перебитыл кости рук, сросшиеся криво, и седые волосы. Никогда не забуду!

Руев Я.Е.: В деревне Черня Сумской области после разгрома немецкого гарнизона мы извлекли из колодияа 180 детских трупиков с выстрелом в затылок. Попавших в плен партизан истязали страшно: пытали всячески, вплоть до вырезания на груди или спине пятиконечных звезд и посыпания их солью.

Денисов Владимир Иванович: Севастополь... и снова над головой свист «мессеримиттов» ${ }^{l}$ завывание мин и огонь, дым пожарищ... Куда не посмотришь - все вокруг в огне, а рядом смерть. Смерть от пуль, осколков снарядов, голод и мучительная жажда, хотя бы один глоток. День сменялся ночью, но и она не несла передышки. Казалось, что больших страданий от близости смерти на свете и быть не может, но самое ужасное многих ждало впереди. Уход из Севастополя последними был рискованным: кругом немць и прорвать их окружение не было сил и техники. Три года в Германии - кошмарный сон, и даже сейчас спустя четверть века, вспоминать о тех днях очень тяжело, не думал, что вернусь на Родину живым...

Сумкин М.И.: Сейчас вспомнился мне один эпизод, который произошел уже в 1946 г. в Сосновском районе Ровенской области. Бойщь прочесали большой массив леса. Затем вышли к деревне, где осмотрели и проверили каждый сарай, потому что в те времена бесчинствовали в том районе фашистские наймиты. В деревне бандитов не оказалось. Выпил на хутор. И вот здесь-то в подвале дома, нашли тщцательно замаскированное в земле небольшое убежище. Опасаясь встречного огня, осторожно вскрыли его и к удивлению намему увидели испуганного мальчика лет 13-14. Помню, звали его Гришей, фамилию забыл, но она была еврейская. Бледный, худой, изможденный и заросший парнишка дрожал, как осиновый лист. По впальм бледным щзекам текли слезы. Бойщь взяли его, по-солдатски обласкали, накормили хлебом и консервами и увезли в гарнизон. Этот мальчик, узник-герой, сидел в подземелье с июня 1941 г. Сидел в одиночке, редко видел солнце. И только по ночам старушка-хозяйка выпускала его в хату, где он и спал вместе с ней на одной кровати. Бабушка рассказала нам, что родители его были евреи. В июне 1941 г. они привели его к ней и попросили во чтобы то ни стало сохранить его жизнь. Оставили ей деньги и провизии. Неграмотная старуха и после освобождения местности от немцев не решалась сообщить о мальчике, боясь расправы бандитов над ним, от них тоже можно было ожидать жестокости (ГАКО. Ф. Р-551. ОП. 1. Д. 23).

Вместе с тем, самое ужасное заключалось в том, что с наступлением мирной жизни испытания для этих людей после освобождения не заканчивались. Нетрудно догадаться, что после получения физических и моральных увечий в плену, уже освобожденные узники должны были доказывать свою невиновность и верность СССР. Что попали в плен, потому что не смогли застрелиться, что успели закопать документы и поэтому их

\footnotetext{
${ }^{1}$ Мессершмитт АГ (нем. Messerschmitt AG) - самолетостроительная фирма Германии (в 1938-
} 1945 годах) и ФРГ (в 1956-1968 годах). 
не расстреляли, а только пытали. Организовывались специальные комиссии по проверке данных о плене, проводились следствия, в которых боевые товарищи или очевидцы боя (если таковые находились) подтверждали слова узника, что это не было дезертирством на сторону врага. И бесконечные протокольl... Некоторых исключали из партии, лишали званий и должностей, но так как учителя и профессиональные кадры были нужны, многим разрешали возвращаться в родные места и заниматься педагогикой.

\section{Фронтовая поэзия}

Чтобы немного отвлечься от ужасов лагерей и фронта, хотелось бы добавить фрагмент о творческой жизни солдат. Именно творчество помогало им справляться и переживать самые страшные минуты в жизни. По воспоминаниям это были записи в дневниках, поэзия, живопись или рисунок и другие формы искусства. Почти в каждом воспоминании учителей, касаемо вопроса о том, какими Вы были, цитировалось стихотворение Николая Майорова, 1942 г.:

\footnotetext{
Мы были высоки, русоволосы,

Вы в книгах прочитаете как миф,

О людях, что ушли не долюбив.

Не докурив последней папиросы.

И как бы ни давила память годы,

Нас не забудут потому вовек

Что все планете, делая погоду,

Мы в плоть одели слово «Человек».
}

Николай Майоров, 1942.

Многие говорили о том, что книга и чтение успокаивало, что именно художественная литература, сборники стихов и рассказов, которые удавалось достать или «раздобыть» во время боевых действий, помогали отвлечься от бессонных ночей, успокоиться, настроиться на мирный лад и снизить уровень тревоги.

Некоторые бойцы сами начинали писать стихи и посвящали строки своим командирам, жертвовавшим своей жизнью для спасения солдат:

Есть в русском офииере обаянье,

Увидишь - и ты готов за ним на самое большое испытание

Идти сквозь бурю, сквозь огонь и дым

Он как отеи и нет для нас дороже

Людей на этом боевом пути...

(ГАКО. Ф. Р-551. On. 1. Д. 23).

Это стихотворение было написано в письме к жене о боевом руководителе Василии Авксентьевиче его полковыми товарищами, где сообщалось, что он погиб при спасении своего друга...

Были и патриотические стихотворения, которые настраивали на победу, что сдаться солдат не имеет право, особенно если он был партийными или хотел таким стать.

\footnotetext{
Если стал человек коммунистом,

Если сердие народу отдал,

Значит, выдержи, вытерпи, выстой

Закались, как звенящий металл
}

(ГАКО. Ф. Р-551. On. 1. Д. 23).

Необходимо отметить, что в годы Великой Отечественной войны количество желающих вступить в партию значительно увеличилось, а процедура принятия была 
упрощена. Эта мера была вынужденной, потому что в начале войны во многих частях и соединениях Красной армии, моральных дух упал, из-за постоянного отступления, психологического давления и беспрерывных боев. По статистическим данным, за дезертирство, членовредительство, трусость, паникерство, распространение пораженческих настроений было привлечено 2681 чел. к уголовной ответственности, высшую меру наказания (расстрел) получило 605 человек. (Ипполитов 2016: 74). И чтобы повысить моральный и боевой дух Центральный Комитет ВКП (б) 19 августа 1941 г. принял постановление «О порядке приема в партию особо отличившихся в боях красноармейцев и начальствующего состава Красной Армии». Согласно этому постановлению в партию принимали бойцов, отличившихся в боях, по рекомендации трех членов партии, которые знали его не более года. Ранее для того, чтобы стать членом ЦК ВКП (б) требовалось выждать более чем три года (См.: № 41. Протокол заседания 1941).

Вообще боевой дух в солдатах активно поддерживался, особенно среди раненных. Ведь многим предстояло вернуться в строй. Именно поэтому при госпиталях очень часто учителя, прошедшие переквалификацию на медсестру, должны были поднимать боевой настрой и оптимизм находящихся на излечении бойцов. Они читали стихи, рассказывали прозу по памяти, развлекали и отвлекали тяжело раненных бойцов. Обязательно надо было зачитывать сводки о положениях на фронтах, о тяжелых моментах в плену и на захваченных территориях, чтобы каждый понимал уровень ответственности и важности победы.

\section{Стихотворение Александра Часовникова}

\section{МЕТЕЛЬ}

Нам идти далеко...

Окружили снега ворохами,

Навалилась метель,

Холодных холмов намела.

Далеко до села

С огоньками, с теплом,

С петухами...

Хорошо бы дойти

До такого села,

Чтобы тело распарить

На ласковой,

Теплой лежанке,

Чтоб солдатский сухарь

Раздобрел
Под крутым кипятком...

Ни дорог, ни огня,

И не пахнет жильем

И стоянкой -

Все закрыто

Махровым, шершавым

Метельным платком.

Мы идем по сугробам

Под злые

Напевы метели.

Ей - кружить и блуждать,

Нам шагать в темноте

Без дорог.

Наши каски, шинели

В снегу поседели...

Устоим,

Победим И не свалимся с ног.

Кондрашов Владимир Николаевич: $B 1942$ г. на Дону, под Сталинградом, раненный осколками гранаты в грудь и голову, попал в фашистский плен. Помогли мне врачи, тоже военнопленнье и врачи-югославы, работавшие от Международного Красного Креста. В плену я помогал антифашистской организации: писал атифашистские стихи, частушки, составлял тексты для листовок. Восстано- 
виться и не пасть духом помогало творчество, оно будто переносило в другую реальность, заглушая взрывы бомб (ГАКО. Ф. Р-551. ОП. 1. Д. 23).

\section{Мать}

Нам в окопы тихая старушка

Молока в кувшине принесла

- Пейте хлопцы милые ... - и кружку

Нам несмело в руки подала

И от этой старческой заботы

Стало вдруг уютно и тепло.

Не спросили седенькую: кто ты?

Где твое родимое село?

Знали мы: село почти сгорело,

Сыновей дорога далека.

Им, быть может, так же вот несмело

Чья-то мать приносит молока.

Это доброе по своей сути стихотворение сочетает в себе всю народную боль и страдание, показывая ту душевную доброту, о которой мы часто забываем сейчас.

\section{Фронтовая кухня}

Особое место в жизни фронтовиков занимала полевая кухня. Пища была необходима для отдыха и восстановления душевных сил. Кормили на фронте очень хорошо, один из воинов блокады Ленинграда вспоминал, что ему как солдату выдавали по шесть сухарей в день, что было очень много для времён блокады и это помогло выжить не только ему, но и членам его семьи. Именно поэтому кухня была чем-то отвлекающим, что компенсировало тот ужас и страх, которые окружали фронтовиков. Существовали целые книги рецептов, которые тоже были элементами народного творчества, как сделать суп более насыщенным, а похлебку наваристой. Например, Михаил Никитич Белов, преподаватель Костромского педагогического института рассказывал, что случалось и кашу с репейником есть, потому что не хватало витаминов, а чтобы добавить витаминов, насыщенности и вкуса, выкручивались таким способом. Весной, а потом уже ранним летом в суп добавляли разные травы (по сезону). Первым варили суп из мать-и-мачехи, потом из крапивы, щзавеля, но самымм вкусным был суп из зелени (петрушка и укроп), выраставщей к июню. Рецепт этих щей прост и вместе с тем они очень вкусны, несмотря на свою незатейливость. При варке бульона, необходимо было добавить стебли укропа и петрушки (именно стебли без листьев), которые надо проварить отдельно не менее получаса с целой луковицей, чтобы они дали свой неповторимый вкус, насыщенный цвет и аромат бульону, а в конце добавляли еще один «секретный ингредиент» - кусок сливочного масла, но он очень часто отсутствовал и вместо него добавляли топленое или растительное масло. Вообще проблема с авитаминозом и истонченностью организма стояла в армии очень остро, во времена войны многие солдаты страдали от никталопии или гемералопии (более известной в народе как куриная слепота), цинги, пеллагры и др. Все эти недуги сказывались больше на моральном самочувствии солдат. Например, М.Н. Белов вспоминал, что после ранения, он как многие бойцы с легкими ранениями, помогали госпиталям, работая санитарами до окончательного выздоровления. В одно из ночных дежурств, он споткнулся, упал и не смог встать, потому что не видел ничего и у него начался приступ паники, ползком он еле-еле добрался до медпункта, 
и так у него диагностировали никталопию (куриную слепоту). После он переболел еще цингой и в 22 года лишился почти всех зубов. Как вспоминала позже его жена, он был молодым, задорным, веселым, симпатичным, но как ульбнется своими золотыми зубами, так у меня душа в пятки уйдет, и я зажмурюсь от страха. Ведь я его была младше на восемь лет, совсем еще молодая учительница была. Но душевная красота победила и, то как он красиво за мной ухаживал, поменяло мое отношение к нему (ПМА 2008).

Спасались во времена войны не только травами, но и грибами, ягодами, которых было очень много и в перерывах между атаками и боями удавалось собирать и делать заготовки на зиму. Солдаты сушили грибы и травы, это помогало получать хоть какие-то витамины еще и зимой.

Лакомством была картошка в мундире, запеченная на костре. Картошка на фронт шла в основном в виде чипсов, которые делали труженики тыла, на добровольно-принудительной основе. Валентин Анатольевич Кожин, которому в годы войны было 8-12 лет, вспоминал, что мать приносила мешок картошки, которую за ночь надо было почистить, порезать и высушить, как чипсы. Конечно, в одиночку справиться с таким заданием было невозможно, поэтому дети помогали своим родителям, но попробовать было нельзя даже один кусочек, потому что картошку принимали на вес и очень часто докладывали свою, иначе могли обвинить в воровстве социалистического собственности. В других районах СССР (Нижегородской области) делали крахмал и тоже отправляли его на фронт, вероятно для киселя. А вот картошкой в мундире солдаты могли полакомиться только, раздобыв, у мирного населения, так разведчики иногда лакомились во время выполнения боевых спецзаданий (ГАКО Ф. Р-551).

Были также распространены так называемые посылки для воинов. Их формировали школьники, учителя, колхозники. Мирное население часто принуждали брать «обязательство» для формирования таких посылок. Они были важны, потому что поднимали патриотический настрой в солдатах, помогали идти в бой, напоминая о семьях в тылу. Дети и женщины шили кисеты для табака, вязали носки, перчатки, обязательно клали продуктовый набор, в основном это был сахар или сушеные ягоды и грибы. Многие фронтовики, имеющие семьи и знавшие из писем о трудностях с продовольствием в тылу и какими жертвами добыт этот кусок сахара или сухарь, отказывались от продуктовых гостинцев и отдавали на кухню, «не мог есть, зная, что мои родные детки там голодают!» (ГАКО Ф. Р-551).

Ценность этого исследования заключается в том, что мемуары учителей, переживших войну, публикуются впервые, схожесть сюжетов не умаляет их роли и исторической важности, ведь история каждого «маленького» человека должна быть занесена в книгу Памяти о войне. Сейчас стало модно ругать и принижать заслуги СССР в угоду Западу и США, которые якобы и являются истинными победителями во Второй мировой войне. Я считаю это незаслуженным, и личные истории о подвигах военных лет доказывают, что 9 мая - День великой Победы советского народа. И без усилия нашей страны она не состоялась бы.

Вместе с тем несправедливость, царящая вокруг памяти и заслуг, достижений и победы советских воинов и тружеников тыла подрывают их авторитет в первую 
очередь в глазах нашей молодежи, сеют сомнения в юных сердцах. И о последствиях этого стоит задуматься, потому что как мы уже говорили, очевидцев и участников-ветеранов с каждым годом остается все меньше и меньше, а их образы и заслуги неизбежно стирает время. И наша главная задача исследовать сюжеты о войне, подвигах и героических историях, рассказывая о них в школах, ВУЗах, СУЗах, а также организовывать семинары, конференции и круглые столы, где молодежь будет говорить о героях своей семьи. Важно, чтобы как можно больше молодых людей задавалось вопросом - а что если бы не было тех героев? Ведь по сути большинство из них были в возрасте 17-25 лет. Груздев (И.О. не указано - Н.Б.): «И с первых дней ответственность за товарищей: ты командир отделения и забота о каждом из них ложится на твои плечи. А тебе 17 лет и ты впервые без маминой опеки» (ГАКО. Ф. Р-551. Оп. 1. Д. 23. Л. 69).

\section{Осколок}

Разрывов гулкие раскаты

Речную рвали тишину

Меня немецкая граната

Изрешетила на Дону.

$<\ldots>$

Тот путь был яростен и долог

Терпи, мужайся и иди...

А я ношу с тех пор осколок.

Железный глубоко в груди.

Тех ран уж нет, сквозных и рваных:

Рубцами заросли давно.

В душе не зарастают раны:
Ей право это не дано.

Вглядись, товарищ мир прекрасен,

Как свет зари - как утра свет!

Пусть небосклон наш будет ясен,

Без смерча ядерных ракет!

Учитель я, и слово «дети»,

Как жизнь, священно для меня.

И я, и ты за них в ответе,

Мы - им защита от огня.

Не будет снова мир расколот!

Мы не допустим, не дадим!

Так требует и мой осколок.

Железный. Глубоко. В груди...

\section{Источники и материалы}

ГАКО. Ф. Р-551 - Государственный архив Костромской области. Ф. Р-551. Оп. 1. Д. 23.

ГАКО Ф. № 41 - Государственный архив Костромской области. Ф. № 41. Протокол заседания подкомиссии по партийно-политической работе в военное время. http://www.plam.ru/ hist/_zimnjaja_voina_rabota_nad_oshibkami_aprel_mai_1940_g/p61.php.

ПМА 2008 - Полевые материалы автора. Кострома, интервью с М.Н. Беловым, В.И. Беловой, Л.Т. Кожиной, В.А. Кожиным о военных временах, 2008.

\section{Научная литература}

Ипполитов Г.М. К вопросу о перестройке партийно-политической работы в Красной армии в начальный период Великой Отечественной войны (22 июня-июль 1941 г.) // Известия Самарского научного центра Российской академии наук, 2016. Т. 16. № 6. С. 72-82.

\section{References}

Ippolitov, G.M. 2016. K voprosu o perestroike partiino-politicheskoi raboty v Krasnoi armii v nachal'nyi period Velikoi Otechestvennoi voiny (22 iiunia- iiul' 1941 g.) [On the issue of restructuring party political work in the Red Army during the initial period of World War II (June 22 - July 1941)]. Izvestiia Samarskogo nauchnogo tsentra Rossiiskoi akademii nauk 16 (6): 72-82. 


\section{Belova, Natalia A.}

\section{"Knights Without Fear": Memories of Teachers - Participants of the Great Patriotic} War

Based on ego-documents, the article tells the frontline stories of teachers who took part in the Great Patriotic War. These stories were written for the 20th anniversary of the victory, but censorship of the Soviet era did not allow the collection to be published. The memoirs preserved in the State Archives of the Kostroma Region (GAKO) testify to the terrible events of the time when the expression "peaceful sky" becomes symbolic. The importance of these ego-documents is that they are direct evidence of the events that happened 75 years ago. Each Russian family has heroes who participated in this historic event: some of them fought, and some worked on the home front. Our objective is to talk about these feats so that they do not fall into oblivion. That is why we prepared an article in which Soviet teachers recall life and deeds on the fronts of World War II. We tried to talk about the main aspects of that difficult period, about how people had to survive and get out of the mental crises after the shocks they experienced.

Key words: ego-documents, World War II, life, front, feats, teachers 